\title{
Ideologies underpinning the Indonesian National Qualification Framework (IQF) for higher education website text
}

\author{
Untung Yuwono \\ Department of Linguistics, Faculty of Humanities, Universitas Indonesia, UI Campus, Depok 16424, Indonesia
}

\begin{abstract}
Political and economic globalization has influenced the education sector. A significant component of education is the process of facilitating students' acquisition of competence and values to enter the job market. The standard of competence at every level of education thus becomes the benchmark for the accurate estimation of a person's success in the job market. Indonesia was not left behind in this trend, and the concept of the National Qualification Framework came into being. The first milestone occurred in 2012 when the Kerangka Kualifikasi Nasional Indonesia (Indonesian National Qualification Framework [IQF]) began to be enforced by the government of Indonesia, and the planning and implementing phases of IQF were conducted. One of these phases is the socialization and dissemination of information on the IQF in higher education through a website (kkni-kemenristekdikti.org) hereafter called the IQF website. This paper qualitatively and quantitatively examines the ideas outlined in the IQF website text using critical discourse analysis framework. Through the textual analysis using systemic functional linguistics, this paper identifies the values highlighted by the IQF and shows that IQF is closely related to the working world. The word kerja (work/job), which appears throughout the text, collocates to words that manifest actors, institutions, processes, products, and values, and its use suggests that it is intended as the primary objective of the IQF. The textual analysis reveals that the context of neoliberalism and work within the workforce has become the trigger for change in national education in Indonesia. The purpose of higher education is now based on global pragmatism, that is, to provide students with competence in accordance with the needs of the job market, and, as a result, all educational regulations are directed to meet the demands of the job market, which ultimately shape the goals and competence levels of the IQF.
\end{abstract}

Keywords: critical discourse analysis (CDA); Indonesian National Qualification Framework (IQF); work/job; neoliberalism; systemic functional linguistics

\begin{tabular}{|c|c|c|}
\hline $\begin{array}{l}\text { First Received: } \\
\text { 23 January } 2018 \\
\text { Final Proof Received: } \\
\text { 29 January } 2019\end{array}$ & $\begin{array}{c}\text { Revised: } \\
25 \text { November } 2018\end{array}$ & $\begin{array}{l}\text { Accepted: } \\
\text { 25 December } 2018 \\
\text { Published: } \\
\text { 31 January } 2019\end{array}$ \\
\hline \multicolumn{3}{|c|}{$\begin{array}{l}\text { How to cite (in APA style): } \\
\text { Yuwono, U. (2019). Ideologies underpinning the Indonesian National Qualification Framework } \\
\text { (IQF) for higher education website text. Indonesian Journal of Applied Linguistics, } 8 \text {, } \\
\text { 668-677. doi: 10.17509/ijal.v8i3.15271 }\end{array}$} \\
\hline
\end{tabular}

\section{INTRODUCTION}

For the world of education in Indonesia, 2012 was a historic year. Two national documents, which are the Presidential Regulation of the Republic of Indonesia Number 8 of 2012 on the Indonesian National Qualification Framework (IQF) and the Law of the Republic of Indonesia Number 12 of 2012 on Higher Education, are issued by the Government of the
Republic of Indonesia. The documents mandate the new direction of the higher education, which is the IQF be the main reference for determining competence for all academic, vocational, and professional education graduates. The first paragraph of Article 29 in the Law Number 12 of 2012 defines the IQF as the learning outcome levels that standardize output in formal, nonformal, informal education, or work experience to 
acknowledge work competence according to different occupational structures in various sectors.

IQF becomes a new paradigm of Indonesian formal higher education that directs the importance of the determination of competencies to be achieved by graduates in accordance with the needs of the labour market. IQF seems to follow the current trend of education in the international sphere, namely education that standardizes graduate competencies in order to meet the demands of the professional sectors. The paradigm, therefore, demands closer relations between professional stakeholders and higher education institutions in determining the competencies given to students during their study in higher education.

The national qualification framework (NQF) seems to be a solution to many of the problems with education and training systems, based on similar diagnoses of problems across countries (Allais, 2011). The discussion on the gap between education and training with the real work situation often appears in public discourse. Then, NQF, including IQF, acts as a specific policy tool that functions as a major instrument for the reform and expansion of educational provision in ways that will raise skills levels, improve labour market productivity, and contribute to economic growth.

Many countries have developed NQF. Initially, in the 1980s the qualification framework was used in vocational education to develop a new system of qualifications that delivered the skills needed by industry but then developed to all levels of study, including master and doctorate levels. By the mid-1990s NQFs were established or in the process of being established in Australia, England, New Zealand, Scotland, and South Africa. From about 2005, NQFs were developed in the Asia-Pacific region. Now all European Union countries have developed comprehensive NQFs.

The discourse surrounding the IQF continues to develop, particularly in institutions of higher education that produce graduates with the highest qualification, which are explicitly identified as subject to the IQF in the Law Number 12 of 2012. The IQF documents state that the implementation of qualification standardization for education and work training with work experience would begin in 2016. To implement the IQF, the Ministry of Research, Technology, and Higher Education (Kemenristekdikti) provided support to disseminate the IQF in various forms.

One product of this support was the website kknikemenristekdikti.org, that is, the IQF website. It was expected that on the website, IQF information would be accessible to the public. The website gathers all available information on IQF, shaping and disseminating IQF discourse, thereby indicating what is happening in social reality to consumers of that discourse (Fairclough, 1992, 1995); this can appear in the form of social change that is represented in a discourse, which presents the actors involved as well as the current events and signs of change. A similar thing occurs with the IQF discourse; the IQF, as the new education policy, causes higher education institutions to begin evaluating what they have taught their students and institutes a new educational paradigm following the application of the competency-based curriculum. As the name implies, a competency-based curriculum is structured based on the competencies needed by the professional sectors so that it becomes a curriculum model that is in line with the spirit of IQF.

Following the assumption that the IQF website discourse also represents the latest dynamic tendency in education in Indonesia, this paper examines the social signs that appear on the website using critical discourse analysis (CDA) of the language used on the IQF website. The IQF is a sign conveyed textually through the website which represents social events in the field of education. By interpreting the language used in the IQF website, thoughts and objectives underlying the issuance of IQF can be revealed. Following the CDA framework model of Norman Fairclough (1992, 1995), a staged analysis is conducted starting from the stage of text description, text interpretation, until text explanation that reveals the thoughts and objectives for applying the IQF. The counting of transitivity percentage in the stage of text description becomes the gateway for a qualitative explanation of the trends appearing on the IQF website. Using Sketch Engine software, the concordance of keywords representing the social events is then observed and connected to the trendy educational contexts in order to reveal the thoughts and objectives for applying the IQF.

\section{Critical discourse analysis (CDA)}

CDA regards discourse as a socio-cultural practice. A discourse is similar to an iceberg that appears above the surface of the sea-it is the critical analyst's responsibility to reveal the hidden meanings in the discourse (Van Dijk, 1997). Such analysis can eventually disclose the purposes of the statement that have not been clearly revealed and are connected to social relationships, worldviews, and social beliefs influencing the discourse participants. Philips and Jorgensen (2002) state that CDA, as an approach, has provided theory and an empirical method connecting a discourse and its socio-cultural contexts. This paper uses the approach of Norman Fairclough (1992, 1995, 2001,2003 ) as a model to clarify information about IQF from the IQF site, and reveals the viewpoint behind the origins of the IQF.

\section{Norman Fairclough's CDA}

Norman Fairclough's (1992, 1995, 2001, 2003) interest in discourses relates to the social dynamics caused by hidden imbalanced social relations. Norman Fairclough's CDA model focuses on discourse formulation due to social change. Fairclough (1992) elaborates that the discourses hiding education commodification - a new world view at that time-were dominated by vocabulary related to skills, such as skills and competence as well as their collocations, skill training, use of skills, and transfer of skills. 
Fairclough's CDA model consists of three processes of analysis, mutually connected in three discourse dimensions as follows: text, practice, and socio-cultural-historical context. Each dimension requires different analyses - a text description for the text, a text interpretation for discourse practice, and a text explanation for the socio-cultural-historical context. These three analytical processes show that Fairclough's model pays attention to linguistic aspects as well as the contexts outside of texts.

The text description is the point of departure for interpretation and explanation to reveal the ideas hidden in the text. In developing his CDA through text analysis, Fairclough came in touch with the thoughts of M.A.K. Halliday $(1985,1994,2004,2014)$ in the systemic functional linguistics (SFL) framework. He was fascinated by Halliday's thoughts and found language works in context and that explaining the relationship between text and context should focus on functional explanations. Halliday confirmed this with his analysis model. Fairclough, therefore, maintains that language analysis conducted via text description refers to SFL analysis. Text interpretation is, furthermore, the development of language analysis seeking interpersonal relationships between the parties producing texts and those consuming texts. The relationship between production and consumption reveals the discourse practice among the discourse participants. Text interpretation is thus often considered production and consumption analysis. Explanations of discourse are conducted by expanding the areas of context to the outermost layers, such as the institutional, societal, and even cultural context. SFL cannot be separated from the context of language use (Liang \& Shin, 2018). At the outermost context layers - the worldview or social beliefs, better known as the ideology - are the most subtle and are often hidden or disguised in a discourse. Language analysis provides the key to interpretation, which is then connected to a relationship analysis of participants in the discourse and the socio-culturalhistorical context that surrounds discourse creation using intertexts, thus revealing the ideology influencing discourse production.

\section{SFL: Clause as message, exchange, and representation}

The key to CDA lies in text analysis. The text is a language dimension and, with the Fairclough model, text description is implemented through SFL-based text analysis, as developed by Halliday. Halliday (2014, p. 83) maintains that the clause becomes the analysis center for linguistic analysis because it represents what is happening in the social context, namely the message, exchange, and representation. The clause system is constructed into the following three separate metafunctions: textual, interpersonal, and experiential or ideational. The ideational function is the representation of an experience, including where, when, and how logical relationships occur. The interpersonal function reveals a relationship among the participants involved in an event or a tendency. The textual function connects the ideational and interpersonal function through a textual organization, which is related to how events or tendencies and the social relationships among the participants are represented in a discourse. The metafunctions evolve in a language being used as a form of action, as a means of enacting interpersonal relations, and also as a means of creating textual coherence connecting the language and its context. (Hasan, 2014).

\section{Clause as message: Theme $^{\wedge}$ Rheme}

The textual function is related to the role of the clause as the information carrier. The text producer chooses information as the starting point of a conversation and what is delivered later. This second definition draws our attention to the thematic structure, which is the configuration of theme ${ }^{\wedge}$ rheme. The thematic structure consists of theme and rheme. The theme is the starting point of a message and is placed in a certain position; in the Indonesian language, the theme is placed at the beginning of a clause. The part that follows the theme is the rheme, which develops the theme within the clause.

\section{Clause as exchange}

When delivering a message, someone plays the role of provider and requester of information, goods, or services. In the grammatical context, the realization of the exchange roles is called the mood. There are two types of mood as follows: (1) indicative, where what is exchanged is information; and (2) imperative, where what is exchanged is goods and service. The indicative mood is further divided into (1) declarative, where information is given, and (2) interrogative, where information is requested.

In a clause, the indicative mood is characterized by the presence of mood elements, consisting of subjects and verbs, and the order of these elements. The subject can be confirmed or denied by the proposition (the part following the mood is called the residue) and refers to an entity that can confirm or deny the proposition. In the indicative mood, the subject guarantees the success or failure of a proposition (or residue) following the mood.

\section{Clause as experience}

As an experiential representation of social reality, a clause presents a process. A process is a combination of finite verb and interpersonal predicator. An experience involves a participant of the experience, and participants are involved in a process within a certain set of circumstances. There are six types of processes as follows: (1) material, (2) behavioral, (3) mental, (4) verbal, (5) relational, and (6) existential, each of which yields a different category of meaning. The process is also closely related to the participant. The functional relationship between process and participant is called transitivity. Table 1 shows the types of processes contained in each meaning category, as well as the participants generally involved in the process. 
Table 1. Types of processes, meanings, and participants (Halliday, 2014, p. 311)

\begin{tabular}{|c|c|c|c|}
\hline Process type & Category meaning & Participants, directly involved & Participants, obliquely involved \\
\hline $\begin{array}{l}\text { material: } \\
\text { action } \\
\text { event }\end{array}$ & $\begin{array}{l}\text { 'doing' } \\
\text { 'doing' } \\
\text { 'happening' }\end{array}$ & Actor, Goal & $\begin{array}{l}\text { Recipient, Client; Scope; Initiator; } \\
\text { Attribute }\end{array}$ \\
\hline behavioral & 'behaving' & Behaver & Behavior \\
\hline $\begin{array}{l}\text { mental: } \\
\quad \text { perception } \\
\text { cognition } \\
\text { desideration } \\
\text { emotion }\end{array}$ & $\begin{array}{l}\text { 'sensing' } \\
\text { 'seeing' } \\
\text { 'thinking' } \\
\text { 'wanting' } \\
\text { 'feeling' }\end{array}$ & Senser, Phenomenon & \\
\hline verbal & 'saying' & Sayer, Target & Receiver, Verbiage \\
\hline $\begin{array}{l}\text { relational: } \\
\quad \text { attribution } \\
\text { identification }\end{array}$ & $\begin{array}{l}\text { 'being' } \\
\text { 'attributing / } \\
\text { 'identifying ' }\end{array}$ & $\begin{array}{l}\text { Carrier, Attributes, Identified, } \\
\text { Identifier; Token-Value }\end{array}$ & $\begin{array}{l}\text { Attributor, beneficiary, } \\
\text { Assigner }\end{array}$ \\
\hline existential & 'existing' & Existent & \\
\hline
\end{tabular}

\section{Text description of the IQF website}

IQF website is a multimodal text consisting of verbal and nonverbal modes. The nonverbal modes use 15 photos showing the situation of people working and discussing in some places, such as laboratory, mining, etc., and 1 illustrated image of stairs. The working situation shown in the photos reinforces all explanations of the verbal text, whereas the illustrated image of stairs seems to symbolize something is climbing up, such as levels of study or career pathway, which also relates to the explanation of IQF in the verbal modes. The next analysis focuses on verbal modes.

The textual function of the IQF website is the presentation of expository texts. Considering the many relational clauses, the text forms an encyclopedic expository genre, starting from a formal definition, followed by the history of the IQF's emergence, and leading to the concepts that became an inseparable part of the IQF.

The IQF word is dominantly used as the starting point in every menu display. Most of the texts on the IQF website appear to be formed of lists of long sentences rather than paragraphs, as most paragraphs are dominated by one long sentence. It tends that the web organizer provides as much detail as possible about IQF. The IQF website contains texts with the clause and word counts shown in Table 2.

Table 2. The number of constructions in the IQF website

\begin{tabular}{lr}
\hline Construction & Number \\
\hline Clause & 200 \\
Word & 3,221 \\
\hline
\end{tabular}

The menu contains the following options:

1. Welcome!

2. Regulations

3. Definition, there is a drop-down menu providing options to go to 4 and 5 consecutively

4. Paradigm

5. Leveling
6. Purposes, there is a drop-down menu providing options to go to 7

7. Advantages

8. Development, there is a drop-down menu providing options to go to $9-11$

9. Development Principles

10. Development Stages

11. Development in Higher Education

12. Application, there is a drop-down menu providing options to go to 13,14 and 15

13. Higher Education, consisting of 13.1-13.4: 13.1 Learning Outcomes

13.2 Previous Learning Recognition

13.3 Diploma Supplement

13.4 IQF Descriptors

14. Society Education

15. International

Menu items 2-12 focus on the IQF, so they can be understood as IQF Regulations, IQF Definition, and so forth. Menu items 13-15 contain more detailed specifications of the terminology related to the IQF.

The clause transitivity of the website text reveals how the IQF website represents what is going on in the education sector in Indonesia; the number of clauses for each transitivity type are shown in Table 3.

Table 3. The number of transitivity in the IQF website

\begin{tabular}{llrr}
\hline No. & Transitivity & $\begin{array}{c}\text { Number of } \\
\text { Clauses }\end{array}$ & $\begin{array}{c}\text { Percentage } \\
(\mathbf{\%})\end{array}$ \\
\hline 1. & Relational & 91 & 45.50 \\
2. & Material & 85 & 42.50 \\
3. & Mental & 11 & 5.50 \\
4. & Verbal & 9 & 4.50 \\
5. & Existential & 3 & 1.50 \\
6. & Behavioral & 1 & 0.50 \\
\hline \multicolumn{2}{l}{ Total Number of } \\
Clauses
\end{tabular}

The identification and characterization of products or services are represented by relational clauses (Halliday, 2014). As shown in Table 3, the highest 
proportion of clauses on the IQF website are relational clauses, with 91 clauses $(45.50 \%)$. The IQF and concepts related to IQF are significant among the concepts identified and characterized by the text, and as is suitable given the name of its website, the IQF website provides a broad definition of the IQF. The key points of identification and characterization-which is marked with the attributive relational process - of the IQF defined throughout the website are presented in Table 4.

It shows the identification of the IQF as (1) what the IQF stands for, (2) the framework of the human resource qualification leveling as part of the formal definition of the IQF, and (3) a means of assistance providing useful qualifications for work (Numbers 8.1-
4 and 9 in Table 4). Identification of the IQF is marked by types of processes and their target participants, and the identification is also conducted according to one of the main IQF parameters in Numbers 10 and 11.

The IQF website introduces the definition of the IQF with the following relational clause: "The Indonesian National Qualification Framework is the Indonesian human resources qualification leveling framework." This provides the main definition of the IQF, which consists of the framework, leveling, qualification, and Indonesian human resources. The four concepts in the IQF definition are among the ten conceptual words most often used in the IQF website, as shown in Table 5.

Table 4. Identification and characterization of IQF

\begin{tabular}{|c|c|}
\hline Participant & Relational Process \\
\hline & 1. Identification: abbrev \\
\hline & 2. Identification: is \\
\hline & 3. Attributive: related to \\
\hline & 4. Attributive: is \\
\hline & 5. Attributive: as \\
\hline & 6. Attributive: covering \\
\hline
\end{tabular}

Indonesian

National

Qualification

Framework
Participant

KKNI (IQF)

the framework of human resources qualification leveling

the national educational system, national work training system, and national learning outcomes standardization assessment system

1. elaboration of higher regulations

2. steps to achieving high quality and character of human resources for the Indonesian people

3. steps related to the education development program and training program within a national scope

a policy with a connection to and wide implication in society

1. qualification level with the same meaning and standard for learning outcomes for every Indonesian worker

2. nine qualification levels, starting from level 1 (lowest) to level 9 (highest)

3. development of a quality assurance system to monitor and assess any institution related to the education standardization with suitable qualification levels

1. flexibility

2. characteristics

8. Identification: becoming

1. guidelines for:

a. determining learning outcome qualifications

b. determining how to acknowledge learning outcome qualifications

- standardizing qualification among learning outcomes

- developing methods to acknowledge and systematize workforce qualifications from other countries

2. one of the programs to enhance quality for producers or users of the workforce

3. guidelines for new work seekers and old workers to improve their standard of living or career in their respective workplace

4. references for learning outcome standardization in various sectors in Indonesia

9. Identification: made into an as passive benchmarking, depending on its use and application analogy

Six main 10. Identification: namely

parameters of

IQF
11. Attributive: contained competence in (a) science, (b) knowledge, (c) know-how, (d) skills, (e) affection, and (f) general competence

Qualification descriptors at each level 
Table 5. The most conceptual words in the IQF website

\begin{tabular}{rlcc}
\hline No. & \multicolumn{1}{c}{ Word } & $\begin{array}{c}\text { Word } \\
\text { Frequency }\end{array}$ & $\begin{array}{c}\text { Percentage (Total } \\
\mathbf{3 , 2 2 1} \text { words = 100 \%) }\end{array}$ \\
\hline 1. & kerja (work/job) & 84 & 2.61 \\
2. & KKNI (IQF) & 59 & 1.83 \\
3. & pendidikan (education) & 54 & 1.68 \\
4. & kualifikasi (qualification) & 36 & 1.11 \\
5. & bidang (field) & 31 & 0.96 \\
6. & jenjang (level) & 22 & 0.68 \\
7. & capaian pembelajaran/LO (learning outcomes/LO) & 20 & 0.62 \\
8. & peraturan (regulation) & 20 & 0.62 \\
9. & pelatihan (training) & 16 & 0.49 \\
10. & pengalaman (experience) & 16 & 0.49 \\
\hline
\end{tabular}

The word qualification collocates with level or leveling. The word qualification is emphasized and is repeated because it is part of the main definition of the $\mathrm{IQF}$, which is primarily concerned with qualification levels. Following the definition, qualification levels $1-9$ are presented on the website, as shown by the following example:

\section{$[\ldots]$}

\section{Level 6}

- Able to apply their expertise and use the science, technology, and/or arts in their field in solving problems and able to adapt to the situation they are dealing with.

- Having mastered theoretical concepts of a certain field of science in general and the theoretical concepts of a specific part in that field of science in depth, and able to formulate procedural problem-solving.

- Able to make the right decision based on information and data analyses, and able to provide guidelines in selecting various alternative solutions independently and in a group.

- Responsible for their own work and able to be responsible for the achievement of results for organizational work.

$[\ldots]$

The website characterizes the IQF by providing its attributes, including (1) the connection of KKNI with the system and regulation(s) deploying the IQF (Table 4 , Numbers 3, 4.1-3, 5, and 14), (2) the IQF as a means to produce high quality and character human resources for the nation (Table 4, Numbers 4.2-3), and (3) the $\mathrm{IQF}$ as a whole entity having (a) several parts (Table 4, Numbers 6.1-3), including nine qualification levels and (b) characteristics (Table 4, Numbers 7.1-2). Other characterizations can be seen in Table 4 under the attributive process.

The material process is the second most common textual process type on the website, appearing in 85 clauses $(42.50 \%)$. As with the relational clauses, the material process is mostly found in combination with the IQF. The collocations with IQF that appeared (see Table 6 below) can be divided into the following seven categories: characteristics, implementation, application of the IQF, qualification description, IQF levels (levels 1-9), related systems, and ministry obligations to apply the IQF. This shows the diversification of how the IQF is represented as a material process after being identified and characterized by the relational process.

Transitive active verbs appear most often in the material process. The IQF and related items, although actually inanimate concepts, are represented as actors changing a targeted participant or creating a targeted participant that had been non-existent. An actor who is identified in a text tends to control or has responsibility for other entities (Karimi, Lukin, Moore, Walczak, \& Butow 2018). In this sense, the IQF can change and create something (i.e., a participant following a process); for example, the IQF can "change the educational sector to become competitive, equal, and integrated with the training and work experience and create nine qualification levels." Table 6 summarizes the material processes that appear on the IQF website, expanding on the relational processes presented in Table 4.

\section{Text interpretation: Production and consumption in the IQF website}

The IQF is a legal product governed by Presidential Regulation Number 8 of the Year 2012 and has wide implications for Indonesian society. Although the government is the party that puts the IQF into effect, it is not presented as the subject or operator on the IQF website. Rather, the IQF is presented as the subject in the declarative mood. The foregrounding of the IQF as the active party, rather than the government, is a strategy to convince readers of the importance of the IQF, along with its positive points, rather than a compulsory regulation from the government to be carried out by educational institutions. All texts on the IQF website appear to make a statement along the lines that "the IQF is a legal product that has gone through a set of background checks, considerations, and processes so that it is trustworthy to be applied to education, particularly higher education."

Grammatical activation of the IQF grants authority to the IQF, and this is guaranteed to be trustworthy, as expressed through the imperative mood as shown in Table 7. 
Table 6. Material process of IQF

\begin{tabular}{|c|c|c|}
\hline Participant & Material Process & Participant \\
\hline \multirow{8}{*}{ IQF } & $\begin{array}{lr}\text { 1. Changing: } & \text { comparing, } \\
\text { standardizing, } & \text { and } \\
\text { integrating } & \end{array}$ & $\begin{array}{l}\text { 1. the educational sector with the training sector and } \\
\text { work experience } \\
2 . \text { between education and work training, as well as work } \\
\text { experience to provide work competence recognition in } \\
\text { accordance with the job structure in various sectors }\end{array}$ \\
\hline & 2. Identification: is & by Presidential Regulation Number 8 of the Year 2012 \\
\hline & 3. Creating: arranged & nine qualification levels \\
\hline & 4. Creating: providing & a workforce qualification standardization system in Indonesia \\
\hline & 5. Creating: able to produce & the needs of all parties \\
\hline & 6. Changing: accommodate & trust of the general public \\
\hline & 7. Changing: obtain & $\begin{array}{l}\text { the development of science and technology, the requirements of } \\
\text { science, expertise, and skills at workplaces }\end{array}$ \\
\hline & 8. Changing: anticipate & $\begin{array}{l}\text { opportunities for workforce movement from Indonesia to other } \\
\text { countries and vice versa }\end{array}$ \\
\hline Flexibility of IQF & 9. Changing: provide & wide opportunities for someone to achieve qualification levels \\
\hline IQF Application & 10. Changing: provide & $\begin{array}{l}\text { to } \\
\text { 1. increase the quantity of human resources in Indonesia } \\
\text { 2. increase the contribution of learning outcomes } \\
\text { increase academic mobility }\end{array}$ \\
\hline $\begin{array}{l}\text { Qualification description } \\
\text { in IQF }\end{array}$ & 11. Changing: impact & whole learning outcomes \\
\hline $\begin{array}{l}\text { Determining level } 1 \text { to } \\
\text { level } 9\end{array}$ & 12. Changing: considering & $\begin{array}{l}\text { through comprehensive mapping of the workforce condition in } \\
\text { Indonesia }\end{array}$ \\
\hline $\begin{array}{l}\text { Each IQF qualification } \\
\text { level }\end{array}$ & 13. Changing: conducted & by four main parameters \\
\hline Each level & 14. Changing: set & in a descriptive form \\
\hline $\begin{array}{l}\text { The } 9 \text { qualification } \\
\text { levels in IQF }\end{array}$ & 15. Changing: compiled & descriptors \\
\hline descriptors & 16. Changing: containing & abilities in the field of work \\
\hline
\end{tabular}

Table 7. The Imperative Mood structure in the IQF Website

\begin{tabular}{|c|c|c|c|}
\hline \multirow{2}{*}{ No. } & \multicolumn{2}{|l|}{ Mood } & \multirow{2}{*}{ Residue (Proposal) } \\
\hline & Subject & Modal operator & \\
\hline 1. & IQF & harus (must) & $\begin{array}{l}\text { comprehensively and justly be able to accommodate the needs of all parties } \\
\text { related to workforce and gain trust of the general public }\end{array}$ \\
\hline 2. & $\begin{array}{l}\text { IQF that will } \\
\text { be developed }\end{array}$ & harus (must) & $\begin{array}{l}\text { be flexible so that it can anticipate the developments in science and technology, } \\
\text { as well as the requirements of science, expertise, and skills in the workplace, and } \\
\text { can always be continuously updated }\end{array}$ \\
\hline 3. & $\begin{array}{l}\text { flexibility of } \\
\text { IQF }\end{array}$ & harus (must) & $\begin{array}{l}\text { also be able to provide opportunities as wide as possible for someone to achieve } \\
\text { suitable qualification levels through various systems of education, training, or } \\
\text { work experience, including the transfer from one system to another }\end{array}$ \\
\hline
\end{tabular}

These clauses contain the word harus (must) as an epistemic modal operator stating something compulsory. By placing the IQF as the subject, however, clauses 1-3 do not present an actor who makes it compulsory or the target that must obey it, and this gives the IQF authority concerning these characteristics.

In the above context, the development principles of the national qualification framework create the 
compulsion, while the parties required to develop the IQF and follow the IQF development principles are the IQF designers themselves - in this case, the government. The clause construction not placing an actor and a target in the form of a person or an animate being is a strategy by the website makers to emphasize the positive characteristics of the IQF without giving direct orders to the parties that become the imperative objects.

\section{Explanation: Contextualization of the word kerja ('work/job') in the IQF website}

The birth of the IQF cannot be separated from globalization, which creates demands within the workforce that influence education. The opportunity to create a global work market demands recognized qualification standards. Education or training is the most important sector producing work qualification output, which triggers the need for a qualification framework, to start at a national scale, to create a standardized measure of work qualifications required by employers based on the competencies gained from education or training.

Allais (2007) explains in detail the process of forming the South African National Qualification Framework (NQF). South Africa was one of the first countries to apply an NQF after Scotland, New Zealand, the UK, and Australia in the mid to late 1980s. The NQF concept in South Africa first appeared in 1990, triggered by the democratic transition resulting from a negotiation between the labor union and the industry. The long-lasting politics of apartheid, which discriminated against black people, lowered the competencies among the working black people in South Africa. The racist work recruitment system and black people's low access to education became the source of problems. By borrowing the competence-based curriculum from Australia and the NQF from New Zealand, labor and industry representatives from South Africa acknowledged the necessity of developing a framework for learning outcomes, which was then compiled as the South African NQF. The South African NQF was then implemented as the national policy through Act No. 58 of 1995, and the South African Qualifications Authority (SAQA) was established and placed under the authority of the Ministry of Education and the Ministry of Workforce to develop and implement the NQF, starting at the end of 1997. Prior to 1997, during the NQF design phase, SAQA requested that all educational institutions submit learning outcomes.

The results of the NQF of South Africa have drawn many critiques. Allais (2007), for instance, observes that NQF did not produce a good performance. The results obtained from NQF-based education and training, with fewer than 200,000 people gaining qualifications in 2006, is not significant compared with the 13,863,273 learners studying in formal educational institutions at that time, let alone those who attended training. This happened because the South African educational system was not ready to provide qualifications as stated in the NQF (Allais, 2007, p. 10).

The neoliberal ideology behind the NQF also invited criticism. Neoliberalism is no longer just a political and economic approach. According to Smith, Tesar, and Myers (2016), neoliberalism has become a 'truth regime' that controls and shapes our minds. In other words, neoliberalism has become an ideology that privileges one truth over another. As an ideology, neoliberalism is then recontextualized in various fields, including the field of education. Neoliberalism, emerging alongside globalization, is the belief that the market is the appropriate place to distribute goods and services internationally and the market has to be strengthened and expanded. Strengthening and expanding markets are only possible when markets are free from government control (Fine, 2002, quoted by Allais, 2007, p. 76; Peters, 2012). Even neoliberalism often refers to premises that the government is not responsible for the social welfare of its citizens (Bockman, 2013). In this view, government control and regulation only inhibit the free market promised by globalization, making it more ideal for providing freedom to the market, including the freedom to compete. The competition of the market actors becomes the proper means to enhance the market, as it will bring profit for individuals. The privatization of industry and services becomes essential, and, as a result, the stakeholders in the workforce, who mostly come from the private sector, demand work qualifications. Unfortunately, however, those demands are not easily met and accommodated by education, as the education sector is not ready (Allais, 2007).

In the context of market competition, the workforce is estimated or paid based on their obtained qualifications (Palley, 2005, as quoted by Allais, 2007, p. 76). Technological development, as a mark of globalization, allows the market use automation to reduce fees for goods and services. Work qualifications are adjusted along with the market developments and as by the goods and service industry to reduce costs.

In the IQF, the word kerja is a keyword that reflects the objective of education and training. The word kerja can be found in collocations everywhere on the IQF website, including phrases such as work experience, work abilities, work training, work competence recognition, job market, workforce, workplace, workforce users, and job seekers. Those collocations demonstrate the importance of education and training for work preparation. Education is directed to provide work qualifications and prepare society to do high-quality work. Education is even directed to increase the accessibility of Indonesian human resources on the national and international job markets. In that sense, the standardization and recognition of work qualifications are needed. Qualification standards are created not only between producers of the workforce and employers but also through the qualifications required by employers. The qualifications required by employers for accountants in Indonesia, for instance, 
have to be standardized with the qualifications applied in other countries. The IQF provides this assistance, which can be continued alongside regional and even international qualification frameworks. Neoliberalism plays a role at this point because markets determine the required work qualifications.

Besides the global workforce-related context, the appearance of Law Number 13 of 2001 on Workforce and Government Regulation Number 31 of 2006 on the National Work Training System provided the background for the development of the IQF, causing the many repetitions of the word kerja (84 times; $2.61 \%$ ) on the website. Government Regulation Number 31 of the Year 2006 on the National Work Training System very clearly explains the connection between work qualifications and IQF as follows.

\section{Second Part IQF}

\section{Article 5}

(1) To develop workforce quality, the IQF is designed based on the work competence qualification levels from lowest to highest.

(2) IQF, as referred to in paragraph (1), consists of 9 (nine) levels, starting from certification qualification level 1 (one) to certification qualification level 9 (nine).

(3) IQF, as referred to in paragraph (1), is stipulated with the Presidential Regulation.

The articles show that workforce planning is the starting point of the IQF, even before it was designed, as in the countries that applied the NQF. The workforce began to cooperate with education at the end of 2009 to produce the IQF as shown in the quotation below.

Responding to various problems and challenges Indonesia can be expected to face in education and the workforce, at the end of 2009 the Directorate General of Higher Education of the Kemendikbud (the Ministry of Education and Culture), through activities developed in the environment of the Directorate of Learning and Students Affairs (Belmawa), took an initiative in line with the idea of the Directorate in Charge of Infrastructure and Trained Workforce of the Kemennakertrans (the Ministry of Workforce and Transmigration) to develop a qualification framework at national level which was then named IQF in short. (Direktorat Jenderal Pembelajaran dan Kemahasiswaan Kementerian Riset, Teknologi, dan Pendidikan Tinggi Republik Indonesia, 2015, p. 4)

However, in the midst the neoliberal influence on education with the concept of kerja as the objective and also result of education, the IQF-after the aspect of work-still includes a second objective of education, national character building through the internalization of Pancasila and the 1945 Constitution of the Republic of Indonesia, although this objective seems to be a subsidiary.
The Law Number 20 of 2003 on the National Education System states in Article 2 that national education is based on Pancasila and the 1945 Constitution of the Republic of Indonesia. Furthermore, Article 3 states that the objective of national education is to develop the students' potential and help them become religious and true to the Almighty God, possess a noble character, be healthy, educated, capable, creative, and independent, and become democratic and responsible citizens. Article 5 of the Law Number 12 of 2012 on Higher Education goes into greater detail on the objectives of higher education, stating that its objectives of higher education are (1) to develop the students' potential to help them become religious and true to the Almighty God, have a noble character, and be healthy, educated, capable, creative, independent, skillful, competent, and civilized for the benefit of the nation; (2) to produce graduates mastering a branch of science and/or technology to meet the national interest and to enhance the nation's competitiveness; (3) to produce science and technology through research that focuses on and applies the value of humanities so that they will be advantageous for the nation's and civilization's progress and the welfare of all humans; and (4) to bring to the fore a dedication to society based on logic and research that is advantageous to welfare in general and can help educate the nation. Nowhere in these laws is the word kerja used as the foundation or objective of national education.

\section{CONCLUSION}

The CDA of the text from the IQF website revealed the ideational, interpersonal, and textual functions of the website. In the textual description phase, covering ideation, the website is dominated by the relational and material processes. The relational process reveals that the website objective is to present a concept of education, that is the IQF. IQF directs higher education to provide students with competencies that are in line with the needs of the job market in the professional community. The material process enriches the identification and characterization given to the IQF by representing the IQF as a concept that is capable of changing and creating a new condition in the field of education. The text of the website foregrounds the IQF as a lexical actor in declarative clauses; as the actor acting upon the target, the IQF is given authority as a representative of the government, which designed the IQF. The activation of the IQF in terms of intransitivity and mood presents the IQF in a positive light to gain the trust of the stakeholders, an approach strengthened by placing the IQF as the theme at the beginning of clauses for every menu item.

The explanation phase revealed that the IQF concept described through transitivity is not a coincidence or the original idea of the Indonesian government, but it is influenced by global phenomena and, in particular, was triggered by workforce globalization. Workforce mobility, as an effect of 
globalization, requires preparation for a recognized workforce standard. This paper has briefly touched on this matter and has not discussed the real workforce conditions in Indonesia, which should also become a trigger for the design and application of the IQF.

From this analysis, we can also see that there is a transformation in Indonesian education triggered by neoliberalism. The increased use of the word kerja as an essential educational objective in Indonesia strengthens educational pragmatism because the objective specifically aims to recognize work qualifications obtained from the learning experience and training in an educational program, as well as training in accordance with stakeholder requirements.

\section{ACKNOWLEDGEMENT}

The author would like to thank Enago (www.enago.com) for the English language review.

\section{REFERENCES}

Allais, S. (2007). The rise and fall of the NQF: A critical analysis of the South African National Qualifications Framework. (Unpublished doctoral dissertation) University of Witwatersrand, South Africa.

Allais, S. (2011). 'What is a National Qualifications Framework? Considerations from a Study of National Qualifications Frameworks from 16 countries'. Journal of Contemporary Educational Studies 5, 106-124.

Bockman, J. (2013). Neoliberalism. Contexts, 12(3), 14-15. doi: 10.1177/1536504213499873

Direktorat Jenderal Pembelajaran dan Kemahasiswaan Kementerian Riset, Teknologi, dan Pendidikan Tinggi Republik Indonesia. (2015). Kerangka Kualifikasi Nasional Indonesia: Dokumen 001. Retrieved from: http://kknikemenristekdikti.org/asset/pdf/001dokumen_kkni.pdf

Fairclough, N. (1992). Discourse and social change. Cambridge: Polity Press.

Fairclough, N. (1995). Critical discourse analysis: The critical study of language. London: Longman.

Fairclough, N. (2001). Language and power. London: Longman.

Fairclough, N. (2003). Analysing discourse: Textual analysis for social research. New York: Routledge.

Halliday, M. A. K. (1985) An introduction to functional grammar ( $1^{\text {st }}$ edn.). London: Edward Arnold.
Halliday, M. A. K. (1994) An introduction to functional grammar ( $2^{\text {nd }}$ edn.). London: Edward Arnold.

Halliday, M. A. K. (2004) An introduction to functional grammar ( $3^{\text {rd }}$ edn. $)$. London: Edward Arnold.

Halliday, M. A. K. (2014). Halliday's introduction to functional grammar( $4^{\text {th }}$ edn.). London: Routledge.

Hasan, R. (2014). 'Towards a paradigmatic description of context: systems, metafunctions, and semantics'. Functional Linguistics, 1(9), 1-54.

Karimi, N., Lukin, A., Moore, A. R., Walczak, A., \& Butow, P. (2018). Advanced cancer patients' construction of self during oncology consultations: a transitivity concordance analysis. Functional Linguistics, 5(1), 6: 1-23.

Liang, F., \& Shin, D. (2018). Uniformity or diversity: Chinese netizens' reactions to language policy through the lenses of critical discourse analysis and systemic functional linguistics. Critical Inquiry in Language Studies, doi: 10.1080/15427587.2018.1527696.

Peraturan Pemerintah Republik Indonesia Nomor 21 Tahun 2006 tentang Sistem Pelatihan Kerja Nasional (the Government Regulation of the Republic of Indonesia Number 21 of the Year 2006 on the National Work Training System).

Peraturan Presiden Republik Indonesia Nomor 8 Tahun 2012 tentang Kerangka Kualifikasi Nasional Indonesia (the Government Regulation of the Republic of Indonesia No. 8/2012 on the Indonesian National Qualification Framework).

Peters, M. A. (2012). 'Neoliberalism, education and the crisis of western capitalism. Policy Futures in Education, 10(2), 134-141.

Philips, L., \& Jorgensen, M. W. (2002). Discourse analysis as theory and method. London: Sage Publication Ltd.

Smith K., Tesar, M., and Myers C.Y. (2016). 'Educapitalism and the governing of early childhood education and care in Australia, New Zealand and the United States'. Global Studies of Childhood 6(1), 123-135.

Undang-Undang Republik Indonesia Nomor 20 Tahun 2003 tentang Sistem Pendidikan Nasional (the Law of the Republic of Indonesia Number 20 of the Year 2003 on the National Education System). (2003).

Undang-Undang Republik Indonesia Nomor 12 Tahun 2012 tentang Pendidikan Tinggi (the Law of the Republic of Indonesia Number 12 of the Year 2012 on Higher Education).

Van Dijk, T. A. (1997). Discourse as interaction in society. In T.A. van Dijk (ed.), Discourse as social interaction. London: Sage. 